УДК 316. 6

PEDAGOGICAL STEREOTYPES AND THEIR IMPACT ON THE PROCESS OF INCLUSION OF CHILDREN WITH SPECIAL EDUCATIONAL NEEDS TO THE GENERAL GROUP / CLASSES

\title{
ПЕДАГОГІЧНІ СТЕРЕОТИПИ ТА ЇХ ВПЛИВ НА ПРОЦЕС ВКЛЮЧЕННЯ ДІТЕЙ 3 ОСОБЛИВИМИ ОСВІТНІМИ ПОТРЕБАМИ ДО ЗАГАЛЬНИХ ГРУП/КЛАСІВ ЗАКЛАДІВ ДОШКІЛЬНОЇ І ПОЧАТКОВОЇ ОСВІТИ
}

Tarnavska N. P. / Тарнавська Н. П. Candidate of Psychological Sciences, Associate Professor ORCID: 0000-0001-5673-9443 Ivan Franko Zhytomyr State University, Velyka Berdychivs'ka, 40 m. Zhytomyr, Ukrayina, 10008

Анотація: У статті розглядається проблема впливу педагогічних стереотипів на прочес включення дітей з особливими освітніми потребами до загальних груп/класів закладів дошкільної і початкової освіти. Аналізуються найбільш поширені педагогічної стереотипи щьодо інклюзивної практики. 3 'ясовано причинно-наслідкові зв 'язки формування стереотипів та можливості їх заміщення. Пропонуються шляхи подолання неефективних педагогічних стереотипів на основі розвитку та закріплення нових уявлень про прочес інклюзії.

Ключові слова: Педагогічні стереотипи, динамічний стереотип, спрощення, типізація, особистісна взаємодія, інклюзивна освіта, діти з особливими освітніми потребами.

Дошкільна освіта України, 3 точки зору сучасних стратегій розвитку, спрямовується на інклюзивний підхід, що передбачає створення умов для життя і освіти 3 повагою до людської гідності, у будь-яких ситуаціях, навіть там, де мають місце дефіцити, пов'язані 3 інвалідністю, фізичними, ментальними порушеннями. Реалізація таких стратегій, неможлива без особистісної орієнтації педагога на цивілізаційні цінності, в основі яких закладені принципи надання однакових можливостей, ресурсів для людей з різними особливостями, потребами, поглядами тощо. Щоб забезпечити добробут кожному члену суспільства, людську гідність та можливість соціальної інклюзії дітей 3 особливими освітніми потребами, необхідно розвивати культуру прийняття, культуру турботи з бажанням не тільки допомогти, а й створити середовище рівних можливостей. При цьому важливо мати розуміння, що різноманітність $\epsilon$ надзвичайно корисною для суспільства i розвитку прогресу. Установки i ціннісні орієнтації педагога мають бути спрямовані на цілковиту допустимість перебування в освітньому просторі дітей, які чимось відрізняються від більшості, але повинні мати ті ж самі стартові можливості. Такі ціннісні установки важко набути в суспільстві, яке довгі роки мало іншу траєкторію розвитку - відособлення від людей з інвалідністю, виділення їх в окрему категорію, яка потребує спеціальних умов (шкіл) i догляду та має бути ізольованою від здорових членів суспільства. Змінити таку ситуацію можливо за певних умов, однією з яких є інклюзивна освіта ще 3 періоду дошкільного дитинства, коли в особистості формуються стійкі нейронні зв'язки, основні базові уявлення про навколишній світ. Організація інклюзивної освіти на етапі дошкільного дитинства передбачає високий рівень вимог до особистості 
педагога закладу дошкільної освіти i його професіоналізму, здатності реалізувати потенціал будь-якої дитини, в тому числі, з інвалідністю, своєчасно розвивати вікові надбання, що стануть базисом для подальших життєвих досягнень. Заклад дошкільної освіти, як перша освітянська ланка, створює комфортні умови для первинної соціальної адаптації дітей, розкриття перед ними багатовимірного світу людських взаємин у їх складності, суперечливості, встановленні тих моделей взаємодії, що передбачають включення людини 3 інвалідністю в активне життя суспільства, побудову 3 нею особистісних, професійних відносин. Вагомим зразком культури прийняття повинно стати середовище закладу, його педагоги, які можуть бути носіями ідей інклюзї̈, справедливого відношення в суспільстві до людей з інвалідністю та показувати суспільству, що існує перспектива успішної самореалізації таких людей, незважаючи на дефіцити, мати достойне життя з почуттям власної гідності та впевненості у завтрашньому дні, що, в свою чергу, запускає процеси дотримання прав і свобод будь-якої людини.

Для реалізації важливого завдання включення дитини 3 особливими освітніми потребами у педагогічний процес вихователю, вчителю важливо відчувати психологічну атмосферу дитячого колективу, прагнути до ефективного співробітництва 3 кожним вихованцем/учнем, адже спосіб взаємодії, вербальний і невербальний контакти дорослого унаслідуються дітьми та переносяться у міжособистісні взаємини. Одним 3 принципів організації сучасної дошкільної освіти є іiі гомоцентричність, що передбачає розвиток особистості дитини як базової складової навчально-виховного процесу [4, 128]. Врахування унікальності i неповторності кожної особистості в освітньому процесі $є$ основою нової культури прийняття, що передбачає зміну позиції допомоги, як специфічного ставлення до дітей 3 інвалідністю, до соціальних уявлень про різноманітність, як культуру прийняття.

Включення дітей з особливими освітніми потребами в заклад дошкільної освіти 3 періоду дошкільного дитинства дозволить здоровим дітям сприймати таку ситуацію як норму життя, формувати таку систему відносин, в яких діти 3 обмеженими можливостями відчуватимуть себе частиною спільноти та такої взаємодії, що дозволятиме робити вибір, відчувати свою особистісну цінність, самостійність і свободу. Спільна гра, навчання сприятимуть вирішенню важливих для усіх задач, поліпшенню спільної справи, адже діти, які зростають, роблячи щось разом, будуть хорошими друзями, партнерами, які мають навички співпраці, що будується на розумінні ресурсів кожного учасника, будуть більш чуйними до інших i зможуть бути продуктивними саме через взаємодію.

Здійснювати інклюзивну освіту в складних економічних і політичних умовах сучасної України, створювати в закладі дошкільної та початкової освіти інклюзивний простір в якому батькам, дітям, педагогам пропонуються ресурси, що забезпечують різноманітність, враховують потреби кожного, доволі складно. 3 одного боку, в педагогів сформовано ряд динамічних стереотипів, пов'язаних 3 ексклюзією, що поширена в минулому та ще має залишки в теперішній системі освіти, оскільки функціонування спеціальних шкіл, шкіл- 
інтернатів для дітей з обмеженими можливостями не припинено, відбувається поступова ї деінституалізація. 3 іншого боку, за статистичними даними Міністерства освіти і науки в 2018 році в закладах дошкільної освіти України виховується 1964 дитини з особливими освітніми потребами і з появою таких дітей в освітньому просторі в педагога поступово утворюються нові динамічні стереотипи, старі ж не зникають - вони взаємодіють 3 новоутвореними, сприяють їх закріпленню, або входять у суперечність 3 ними, унаслідок чого успішне закріплення нових стереотипів гальмується, недостатнім $є$ володіння педагогічним інструментарієм, що необхідний для роботи з групою, до якої включені діти 3 особливими освітніми потребами. Однією 3 ключових педагогічних проблем в Україні $\epsilon$ перенесення «старого» досвіду та змісту в сучасний освітній простір під новими гаслами й гучними формулюваннями. Потрібно усвідомлювати, що зміна однієї парадигми на іншу не $\epsilon$ удосконаленням старої парадигми, що нажаль, відбувається сьогодні, а реконструюванням усієї галузі педагогічних знань на нових засадах. За словами Костянтина Ушинського: «Будь-яка зміна в освіті, неможлива інакше, ніж крізь голову вчителя». Це стосується формування нового категоріального апарату, нових знань про особистість, джерела ії розвитку, це нове уявлення про процес включення дітей дошкільного віку з особливими освітніми потребами до звичайних груп (класів). Перехід системи дошкільної освіти від раціональної моделі, в основі якої лежали трансляція знань і суб'єкт-об'єктні відносини до індивідуально-орієнтованої моделі інклюзивної освіти, в основі якої $\epsilon$ співпраця, взаємодія та суб'єкт-суб'єктні відносини, супроводжується руйнуванням або набуттям нових педагогічних стереотипів.

Досліджуючи педагогічні стереотипи ми спираємося на такі аспекти: соціальні функції стереотипу, формування стереотипів як наслідок соціальної категоризації, Генрі Теджфел (1969); виникнення стереотипів у результаті помилок, заснованих на метафорах, уявних картинках, Джон Холт (1982); стереотипи повсякденної педагогічної свідомості - функціоналізм, ототожнення логіки виховання 3 логікою навчання, підміна цілісного педагогічного процесу сумою ізольованих один від одного заходів, Віталій Сластьонін (1998); взаємодія психологічних механізмів стереотипізації i рефлексії як умова розвитку професійної компетентності вчителя, Олена Рогуліна (2000); вплив стереотипів на формування основних рис педагогічного мислення і діяльності вчителя, Юрій Тюнников (2005); психологічні особливості подолання педагогічних стереотипів у студентів і вихователів дошкільних закладів, Ірина Бучилова (2007).

Стереотипи, відповідно до визначення американського психолога Уолтера Ліпмана (1922 рік) є спрощеними, попередньо сформованими уявленнями про світ, традиційно звичними способами мислення, сприйняття і діяльності, ригідними кодами-знаннями, що застосовуються людиною у готовому вигляді [3]. Педагогічні стереотипи - це когнітивні, або афективні еталони, на які орієнтується педагог у своїй професійній діяльності - це стереотипи мислення, емоцій, реакцій, поведінки. На певному етапі молодому педагогу-практику вони є необхідними та допомагають швидко орієнтуватися у різноманітних 
ситуаціях, будувати свою діяльність у реальних освітніх умовах. Будь-яка складна діяльність не обходиться без системи стандартів та механістичної, технологічної реалізації, але коли парадигма застаріває, то стереотипи, які їй відповідали, стають вагомими перепонами та гальмують оновлення практики. Педагогічні стереотипи дуже живучі. Наявність стереотипного мислення i поведінки обмежують творчість, оскільки алгоритмічний підхід до їі здійснення не $є$ притаманним дошкільній та початковій освіті. Розглянемо основні поняття пов’язані зі стереотипами.

Стереотипізація має такі основні ознаки: спрощення - орієнтування на мінімум, на більш примітивні конструкції; неможливість діяти варіативно 3 великою кількістю складних об'єктів.

Типізація - процес створення моделей, конструкцій на основі спільних характеристик, стандартизація оточуючого. Стереотип застосовується так, щоб не він відповідав феномену світу, а для феномену світу підшуковується відповідний стереотип [2, 13-16].

Відсутність критичності сприйняття - рутинні дії пов'язані зі стереотипами, не піддаються рефлексії, в цьому сенсі стереотипи можна назвати «несвідомими».

Ригідність - (лат. rigidus - твердий, міцний) - стереотипи майже не модифікуються, існує неготовність змінювати програму дій у залежності від нових мотиваційних вимог.

Педагогічні стереотипи, які були характерні для суб'єкт-об'єктної дошкільної і початкової освіти, на жаль, ще й досі залишаються стійкими i несуть серйозну небезпеку в організації інклюзивного навчально-виховного процесу.

У процесі реалізації італійсько-українського проекту співробітництва «Дошкільні заклади та відносини між родиною, суспільством та навчальним закладом щодо дітей 3 особливими потребами від 0 до 6 років у Житомирському регіоні - Україна» (2015-2017 роки) та роботи щорічної (з 2016 року по теперішній час) італійсько-української школи (засновник: професор Університету Парми Дімітріс Аргіропоулос) за партнерської участі Університету Парми, Громадської організації ISCOS Емілія Романья, Регіонального управління Емілія Романья (Італія), Житомирського державного університету в липні 2018 року був розроблений опитувальник і проведено письмове анонімне опитування 57 педагогів (середній вік 42 роки) з різних областей Житомирської області, які працюють у класичних групах (класах) закладів дошкільної і початкової освіти та мають менше двох років досвіду роботи 3 дітьми 3 особливими освітніми потребами, які включені в дитячі колективи. Їм було поставлено два питання відкритого типу, що передбачали розгорнуту відповідь (до 5-ти речень на кожне): 1). Яке ваше ставлення до інклюзивної освіти? (аргументуйте відповідь); 2). Які труднощі у педагогічній діяльності виникли у вас 3 появою в групі дитини (дітей) 3 особливими освітніми потребами? (вкажіть три причин, що спричиняють виникнення труднощів, аргументуйте відповідь).

Отримано наступні результати опитування: 
47\% (27 педагогів) негативно ставляться до впровадження інклюзивної освіти, вони вважають, що дітям з особливими освітніми потребами необхідно навчатися у спеціальних освітніх закладах, оскільки вони потребують корекції і лікування, а існуюча система освіти з розгалуженою мережею спеціальних шкіл та інтернатних установ не повинна ламатися. Аргументуючи відповідь, ця категорія вихователів/вчителів вказує на те, що труднощі в їх роботі спричинені нестачею матеріальних, технічних, інформаційних, методичних ресурсів для прийняття дітей з особливими освітніми потребами, а на педагога покладається ще більше обов'язків щодо розробки супровідної документації, виникають труднощі в роботі з батьки здорових дітей, які негативно налаштовані до такого процесу й висловлюються проти того, щоб діти з особливостями розвитку взаємодіяли 3 їх дітьми, a тому робота педагога 3 батьками значно ускладнюється;

33\% (19 педагогів) висловилися помірковано, вони погоджуються 3 впровадженням інклюзивної освіти за прийнятних для них обставин (умов). Труднощі у своїй діяльності пов'язують 3 організацією роботи 3 дітьми, які мають значний ступінь ментального дефіциту, при цьому вказують на те, що не мають спеціальної освіти для роботи з такою категорією дітей і вважають, що їм краще навчатися в спеціальних закладах освіти. Зазначають, що їм важко налагоджувати взаємодію, дружні стосунки між дітьми групи/класу і дітьми 3 інвалідністю, організовувати навчальну діяльність групи/класу з врахуванням особливих освітніх потреб дітей з інвалідністю. Вказують також на те, що діти 3 особливими освітніми потребами не встигають одночасно з усіма засвоїти навчальний матеріал i, з точки зору педагогів, негативно впливають на інших, їх нетипова поведінка заважає реалізувати програмові завдання і відволікає інших. Аргументуючи відповідь, уточнювали, що випадки дезорганізації навчального процесу відбуваються через те, що, приділяючи більше уваги дитині з особливими освітніми потребами, менше уваги дістається іншим дітям групи, що призводить до порушення дисципліни.

$20 \%$ (11 педагогів) задоволені впровадженням інклюзивної освіти, вказують на позитивні зміни, пов'язані 3 включенням дітей 3 особливими освітніми потребами до класичних груп/класів. Аргументуючи відповіді, зазначають, що присутність дітей з інвалідністю дозволяє дітям групи отримати новий досвід прийняття однолітків, які мають інші особливості, в них розвиваються такі якості як доброта, чуйність, толерантність до оточуючих. Ці педагоги вказують на труднощі в роботі, пов'язані 3 активним включенням дитини 3 особливими освітніми потребами до колективних форм роботи 3 дітьми під час занять/уроків, на складнощі адаптації та модифікації завдань, методів, змісту, засобів. Зазначають також нестачу кваліфікованих асистентів педагога.

Аналізуючи результати опитування 47-ми відсотків респондентів, можна зробити припущення, що негативні погляди педагогів на інклюзивну освіту спричинені наявністю в них стереотипів, сформованих у період ексклюзії дітей 3 інвалідністю, як домінуючого механізму в системі освіти минулих років (основні нормативно-правові акти щодо реалізації інклюзивної освіти в Україні 
прийняті в останні чотири роки). Наявність авторитарних механізмів у системі управління освітніми процесами, що відображаються у взаємодії педагога i дитини. Цей спосіб стосунків, що базується на вище вказаних механізмах, залишається для учасників освітнього процесу стереотипним. Його надзвичайно важко змінити, оскільки він має багаторічну практику застосування і незначну кількість альтернатив. Зміни відбуваються повільно та часто носять декларативний характер. 3 одного боку, педагоги зазначають про своє добре ставлення до людей $з$ інвалідністю, а 3 іншого - воліли б не стикатися з ними в педагогічній діяльності. Засновник теорії когнітивного дисонансу Леон Фестінджер висловлював точку зору про те, що когнітивний дисонанс - це такий стан психіки, який виникає тоді, коли наші переконання розходяться 3 нашими діями. Результатом цього конфлікту є виправдання, які людина собі знаходить. Тому, пояснюючи відповіді на питання, педагоги знаходили аргументи, що виправдовують їх позицію і це є зовнішні чинники, такі як ресурси або кількість дітей в групах тощо. Це дозволяє рухатися стереотипним шляхом, оскільки він простіший ніж шлях перетворень. Людина у таких ситуаціях діє лінійно, це найпростіший спосіб взаємодії - педагог реалізує директиви керівництва, плани, програми уніфіковані для всіх, а від дитини вимагає того, щоб вона добре поводилась і підкорятись, слідувала правилам. Авторитаризм, навіть у незначних проявах, пов'язаний зі схильністю до тривоги і відчуттям небезпеки при зіткненні 3 невизначеністю чи неоднозначністю [стенлі мілград?]. Педагоги 3 авторитарними підходами не люблять змін, вони почувають себе некомфортно коли від однотипності потрібно перейти до різноманітності, діяти не за інструкцією, а виходячи 3 індивідуальних потреб і можливостей дитини. Нетипові особливості дітей асоціюються в них 3 непередбаченістю, різноманітністю, які вимагають багатовекторності в прийнятті рішень, вибору способів дій, адаптації чи модифікації розвиваючого середовища тощо. Відповіді цієї категорії педагогів часто займають полярні позиції та надто категоричні. Серед $47 \%$ опитаних, які зайняли категоричну позицію щодо впровадження інклюзивної освіти, при аргументації відповіді, не зазначалося факторів або умов, які б були прийнятними для них щодо інклюзії. Також можна припустити, що частина респондентів має недостатні уявлення про інклюзію, тому що характер їх відповідей був досить узагальненим. Коли людині пропонують реалізувати щось таке, що для неї є незрозумілим або маловідомим, це спочатку викликає протидію, пізнавальний же інтерес з'являється у процесі подальшої діяльності, якщо вона буде мотивованою.

Педагоги, які займають проміжну позицію (33\%), висувають ряд умов, що спростили би їм процес реалізації інклюзивного навчання, прагнуть залишити систему без особливих змін. При цьому в них змінюються не стереотипи, а, навпаки, до нової реальності підшукуються попередньо сформовані стереотипи, до застарілого досвіду відокремлення дітей 3 особливими освітніми потребами штучно прилаштовуються «нові» підходи, наприклад, дітей зі складними формами інвалідності намагаються вилучати з уроків/занять, а тих, які завдають менше клопоту, долучають до навчального процесу. Ця 
проміжна позиція педагогів щодо можливості працювати тільки 3 дітьми, які мають незначні фізичні або ментальні порушення має подвійні стандарти. Вона шкідлива тим, що створюються не лише обмеження, а й відбувається розподіл дітей $з$ особливими освітніми потребами на окремі групи - тих, кого варто долучати до навчального процесу і тих, хто матиме обмежений доступ через свої дефіцити, що, безперечно, є порушенням прав на здобуття освіти. Разом 3 тим оцінка педагогом збережених функцій дітей, їх потенційних можливостей, компенсаторних механізмів зводиться до складності хвороби. Такий симбіоз застарілих стереотипів і необхідності переходу до цивілізованих змін в освіті підштовхує педагогів шукати таких способів дій, які спрощують їх діяльність але є далекими від моральних цінностей. При цьому педагог не вникає у суть інклюзивного процесу, стереотипи заважають критичності сприйняття, адекватності оцінки, свою стратегію він вважає інклюзивною i часто намагається переконати в цьому інших. Діти з інвалідністю не сприймаються ним як такі, що мають особливі потреби, а як окрема категорія, до якої має бути інше ставлення, інші підходи, тому: «За роботу з такими дітьми має бути спеціальна оплата праці», як зазначається в результатах опитування. При цьому ставлення до здорових дітей з різними особливостями поведінки чи характеру не викликає таких суджень.

Відсутність досвіду інклюзії та інформаційна обмеженість заважає набуттю нових смислових утворень як відповідних цінностей особистості, а стереотипи призводять до подвійних стандартів у ставленні до здорових дітей та дітей 3 особливими освітніми потребами. Поширеними педагогічними стереотипами $\epsilon$ орієнтація на реалізацію завдань програми, чітко структурований план, форми роботи, а не на потреби дітей, зону їх найближчого розвитку. Вказані стереотипи характеризується тим, що згадані орієнтири виступають як мета, а не засіб досягнення результату. При цьому педагог має стандартизований набір установок - діти мають максимально вирішувати всі намічені завдання; структуру заняття/уроку не можна змінювати; заняття/урок буде невдалим, якщо його проводити в нетипових умовах; діти мають недостатній досвід, щоб знаходити власні способи дій та варіанти рішень; без показу зразка, чіткого, визначеного педагогом алгоритму дій не може відбуватися навчальний процес; на заняттях/уроках не може бути вільного темпу діяльності для кожної дитини, оскільки це вносить дезорганізацію; заняття/уроки можуть бути тільки класичними, тільки інтегрованими, тільки тематичними тощо. Стереотипні дії $є$ більш зручними ніж ті, що пов'язані з аналізом і прогнозуванням, проектуванням інклюзивного освітнього простору, через це педагоги схильні вважати, що діти з інвалідністю не встигають одночасно з усіма засвоїти навчальний матеріал. При цьому ними не враховується, що здорові діти так само мають різний темп діяльності, способи засвоєння інформації, одні навчаються з легкістю, а інші докладають значні зусилля, в певний час дітей щось цікавить більше, а в інший стає неактуальним. Цей комплексний i складний процес впливу емоційних, чуттєвих, мотиваційних, стосункових факторів на розвиток особистості притаманний всім дітям, у тому числі, 3 особливими освітніми потребами. 
Однак наявність застарілих педагогічних стереотипів спричиняє з одного боку ситуацію, коли педагог не може сприймати дитину з інвалідністю, як і інших здорових дітей з їх особливостями розвитку, а з іншого, пов'язує перебування такої дитини в колективі з додатковими труднощами для власної педагогічній діяльності - потрібно вести спеціальну документацію, адаптувати, або модифікувати середовище, застосовувати нові форми роботи 3 дітьми. У багатьох випадках освітній процес зводиться до передачі педагогом і відтворенням дітьми «готових форм» соціального досвіду, накопичення навчальної інформації, що є наслідком дії стереотипів, які стосуються способів формування знань, умінь і навичок. Однак рушійні сили психічного розвитку дитини пов'язані, в першу чергу, з саморозвитком. Ж. Піаже пояснює його спонтанним виникненням «психологічних структур», які не залежать від безпосереднього навчання. Темпи і рівень психічного розвитку, зокрема розвитку інтелекту, визначають самі можливості й здатності зрозуміти те, що дається в навчанні. У психічного розвитку свої джерела і рушійні сили, що притаманно як для здорових дітей, так і для дітей 3 особливими освітніми потребами. Вияв цих джерел передує оволодінню тими чи іншими знаннями i вміннями. Варто зазначити, що в усіх випадках навчання розглядається як пристосування педагогічного процесу до розвитку дитини, що є проблемою для педагогів зі стереотипами щодо неможливості змін, застосування гнучких педагогічних моделей. Коли вони унеможливлюють необхідність змін, то розповідають про псевдоістини, які слугують для того, щоб визначити для себе особисту та професійну ідентичність.

3 відповідей 20\% педагогів, що схвалюють впровадження інклюзивної освіти, видно наявність у них мотиваційної готовності до пошуку нових альтернатив що сприятимуть ефективній організації інклюзивного навчання, а ïx погляди і цінності $є$ індикаторами розвиненої особистості. Структуру та функції ціннісної системи людини можна зрозуміти, проаналізувавши наявність стереотипів та їх стійкість по відношенню до активної життєвої позиції особистості. Нормальним станом людини $є$ не стан спокою, а стан активної діяльності, прагнення, мотиваційне напруження. Важливо констатувати ще й той факт, що педагоги останньої групи не вбачають проблем у налагодженні взаємодії між педагогом, дитиною з інвалідністю й дітьми групи. Разом з тим вони вказують на труднощі з адаптацією і модифікацією навчальних завдань $\mathrm{i}$ методик, і ці дидактичні цілі виходять на перший план. Взаємини педагога 3 дітьми та між собою $\epsilon$ одним 3 найважливіших чинників впливу на ефективність освітньогопроцесу. Очевидно, що коли дидактичні цілі стають першочерговими без знання закономірностей, які визначають формування, становлення, зміну або розгортання взаємин, процес інклюзії гальмуватиметься, адже взаємини, їх емоційний компонент передбачає здатність до душевного відгуку, а співпереживання завжди пов'язане 3 емоційними взаєминами між дітьми.

Підсумовуючи вище сказане, закцентуємося на шляхах вирішення проблеми. У реалізації інклюзивної освіти велику роль відіграє те, що педагоги сприймають цей процес через призму власних стійких еталонів (стереотипів). 
Такі еталони часто формуються мимовільно, непомітно для особистості, під впливом емоцій, вражень спонтанних відчуттів. Так, в оцінці дитини педагог часто мимовільно відштовхується від особливостей зовнішнього вигляду, антропологічних ознак, особливостей характеру, поведінки, соціального статусу родини. Оціночні стереотипи педагогів мають, переважно, суб'єктивний, індивідуальний характер, але загальноприйнятими $\epsilon$ такі: «улюбленцями» педагогів, як правило, є діти дисципліновані, слухняні, охайні, ті, які не бешкетують, не створюють проблем - вони отримують найбільш схвальні оцінки, їх асоціюють з успішністю в навчанні. До «проблемних» дітей потрапляють гіперактивні, непосидючі, ті, яким важко дотримуватись правил, поведінка яких часто непередбачувана, мотивація до навчання слабка. Маючи саме такі уявлення, педагог переносить їх на оцінку дітей з інвалідністю і виділяє їх в окрему категорію «не таких як усі». Їх особливості сприймаються не як індивідуальні, що притаманні будь-якій особистості, а як такі, що спричинені хворобою. До таких педагогічних упереджень можна легко знайти контраргументи, але формування нових знань, компетентностей, в тому числі й стереотипів, потребує більш складного системного впливу і практики.

На початкових етапах реалізації інклюзивного навчання в педагога виникають протиріччя між наявними стереотипами та здатністю обирати адекватні засоби і методи включення дітей з особливими освітніми потребами в педагогічний процес, між специфікою попередньої професійної підготовки та новими викликами, пов'язаними 3 реалізацією нових методичних, організаційних функцій, між умовами роботи в закритій, циклічній системі та умовами взаємодії з різними соціальними інститутами - медичними, соціальнопсихологічними, батьківськими, громадськими урядовими та неурядовими організаціями. По суті, це суперництво між професійною творчістю і консервативними установками та стереотипами, що виникли на підгрунті ексклюзивного досвіду.

У той же час не варто акцентуватися лише на негативних аспектах педагогічних стереотипів. Для досвідчених педагогів здатність швидко реагувати на будь-яку ситуацію, що несподівано виникає, автоматично приймати вірне рішення базується на застосуванні педагогічних стереотипів утворених у процесі багаторічної роботи. Педагог з досвідом роботи здатний уникати проекції власного суб'єктивного бачення «проблемної» дитини та абстрагуватися від цього у процесі пізнання індивідуальних особливостей поведінки та мотивів ऑiі діяльності, потенційних можливостей, зони найближчого розвитку. На основі усталених педагогічних стереотипів може успішно розвиватися механізм міжособистісного сприйняття - емпатія (пізнання емоційних станів іншої людини через співпереживання). Для педагога важливо усвідомлювати, що при позитивному сприйнятті дитини з особливими освітніми потребами, іiі дефіцити оцінюватимуться адекватно, існує можливість ефективного включення збережених функцій при налагодженні позитивних, продуктивних взаємовідносин. Зрозуміло, що не усі стереотипи є перепонами для прогресивних змін. Особливо це стосується впорядкованості, прагматичності, відповідальності, навичок співпраці педагога 3 дітьми. Ці 
позитивні стереотипи потребують закріплення вони актуальні у реальній дійсності.

Аналізуючи педагогічні стереотипи щодо реалізації інклюзивної освіти, важливо враховувати персональний досвід педагогів а також особливості освітнього простору конкретного регіону, оскільки велике значення мають різноманітні фактори впливу, що визначають вектор руху в інклюзивному процесі. Усвідомлюючи той факт, що негативні та застарілі стереотипи педагогів варто трансформувати на такі, які будуть корисними самому педагогу, зокрема, та сприятимуть просуванню інклюзивної освітив в цілому, особливу увагу важливо звернути на ті механізми, що показали свою ефективність та спрогнозувати ті, що спрацюють у перспективі. Значний влив на світоглядні позиції та ціннісні орієнтації педагогів Житомирського регіону щодо процесу інклюзії здійснено у процесі реалізації Житомирським державний університетом імені Івана Франка, Університетом Парми, громадською організацією ISCOS регіону Емілія Романья (Італія) навчальних семінарів, інклюзивних італійсько-українських шкіл, де процес зміни цінностей починається знизу від вихователів, учителів закладів загальної освіти, волонтерів, науковців, громадських активістів, асоціацій батьків й поширюється серед широкого загалу педагогів, медичних працівників, громадськості. Враховуючи результати такої роботи важливо відзначити ефективність демонстрації педагогам альтернативних освітніх моделей, можливість усвідомлювати протилежності, здійснювати порівняння i аналіз, вести дискусії та здійснювати моделювання освітнього процесу в нових умовах. Це передбачає здійснення переходу від уніфікованого освітнього простору до багатовекторної системи взаємодії з відповідними особистісно-орієнтованими ознаками та характеристиками. Не менш цінним для фахівців $є$ розуміння особливостей власних стереотипів. Дія стереотипів розпочинається ще до того, як включається мислення, при цьому нівелюються фактичні дані у момент їх сприйняття. Стереотипи можуть набувати нової якості в залежності від зміни умов, об'єктивної оцінки, реагування, аналізу.

\section{Література}

1. Дімітріс Аргіропоулос, А.П. Салацька, Н.П. Тарнавська, I.I. Катинська Організація інклюзивної освіти в дошкільному навчальному закладі: Навчально-методичний посібник для науково-педагогічних працівників, студентів вищих навчальних закладів / Дімітріс Аргіропоулос, А.П. Салацька, Н.П. Тарнавська, І.І. Катинська - Житомир: Вид-во ЖДУ ім. І. Франка, 2016. 202 с. Бех І.Д. Виховання особистості: Підручник. - К.: Либідь, 2008. - 848c., C.34.

2. Калошин В.Ф. Подолання негативних педагогічних стереотипів / В.Ф. Калошин// Упр. шк. - 2008. - № 32. - Вкладка. - С.13-16.

3. Липман У. Внешний мир и его картина в нашем сознании /Пер.с англ. Т.В. Баргуновой // Социологический журнал, № 1, 2003.

4. Нравственность в современном мире. - Мн.: Изд. «Красоко-Прилог», $2003-128$ c., C. 60. 
5. Тарнавська Н.П. Актуалізація превентивної діяльності педагога ДНЗ у запобіганні соціальних небезпек для дітей дошкільного віку // Актуальні проблеми психології: Збірник наукових праць / За ред.. Максименка С. Д. - Т. 7. - Вип. 16 - Житомир: Вид-во ЖДУ ім. І. Франка, 2008 - С 168-172.

Abstract: The article deals with the problem of influence of pedagogical stereotypes on the process of inclusion of children with special educational needs in general groups / classes of preschool and primary education institutions. The most common pedagogical stereotypes regarding inclusive practice are analyzed. The causes and effects of stereotyping and the possibility of their replacement have been clarified. Ways to overcome ineffective pedagogical stereotypes based on the development and consolidation of new ideas about the process of inclusion are offered.

Key words: Pedagogical stereotypes, dynamic stereotype, simplification, typing, personal interaction, inclusive education, children with special educational needs.

Стаття підготовлена в рамках реалізації програми викладацькостудентського обміну «Overworld Exchange», яка передбачає створення індивідуальної мобільності викладачів / студентів університету Парми в Житомирському державному університеті імені Івана Франка та украӥнських студентів в університеті Парми, що регулюється спільним протоколм викладання та наукового співробітниитва (PROTOCOL OF INTERNATIONAL UNIVERSITY COOPERATION FOR EDUCATIONAL AND SCIENTIFIC PURPOSES between the University of Parma Universitä degli Studi di Parma (Italy) and the University "Ivan Franko" of Zhytomyr (UKR) від 12.052016 p.) згідно якого проводяться наукові дослідження з проблематики, важливої для обох

сторін щьоо забезпечення та реалізачї спільних італійсько-українських проектів, впровадження інклюзивної освіти в закладах загальної освіти Житомирського регіону, фахової підготовки педагогічних прачівників в прочесі роботи літніх італійсько-украӥнських шкіл. 